\title{
Normocalcemic primary hyperparathyroidism: long-term follow-up associated with multiple adenomas
}

\author{
Hiperparatireoidismo primário normocalcêmico \\ associado a múltiplos adenomas
}

Larissa Pimentel', Sirley Portela', Alyne Loureiro', Francisco Bandeira'

\begin{abstract}
SUMMARY
Normocalcemic primary hyperparathyroidism (NPHPT) is a condition characterized by elevation of the parathyroid hormone (PTH) in the presence of normal serum calcium and the absence of secondary causes. The case described illustrates the long-term follow-up of a postmenopausal woman with NPHPT patient who progressed with multiple adenomas. This case reports a 77-year-old female who has chronic generalized pain and osteoporosis. Her initial serum PTH was $105 \mathrm{pg} / \mathrm{mL}$, with total serum calcium of $9.6 \mathrm{mg} / \mathrm{dL}$, albumin $4.79 \mathrm{~g} / \mathrm{dL}$, phosphorus $2.8 \mathrm{mg} / \mathrm{dL}$, and $250 \mathrm{HD}$ after supplementation was $34.6 \mathrm{ng} / \mathrm{mL}$. The bone densitometry (BMD) results were as follows: lumbar spine:T-score -3.0, femoral neck:T-score -2.6 and distal radius: -4.2. Other causes of secondary hyperparathyroidism were ruled out and cervical ultrasound and Tc-99-Sestamibi scan were negative. She used oral alendronate and three infusions of zoledronic acid for treatment of osteoporosis. In the $10^{\text {th }}$ year of follow-up, after successive negative cervical imaging, ultrasound showed a nodule suggestive of an enlarged right inferior parathyroid gland. PTH levels in fluid which was obtained during fine-needle aspiration (FNA) were over $5,000 \mathrm{pg} / \mathrm{mL}$ and a Sestamibi scan was negative. The patient underwent parathyroidectomy, and a histological examination confirmed parathyroid adenoma. Post-operatively serum PTH remained elevated in the presence of normal serum calcium levels. A follow-up cervical ultrasound showed a new solid nodule suggestive of an enlarged right superior parathyroid gland. PTH levels in the aspiration fluid were remarkably high. A second parathyroidectomy was performed, with the excision of a histologically confirmed parathyroid adenoma. In conclusion, this is an unusual presentation of NPHPT and highlights the long-term complications. Arq Bras Endocrinol Metab. 2014;58(5):583-6
\end{abstract}

\section{SUMÁRIO}

Hiperparatiroidismo primário normocalcêmico (NPHPT) caracteriza-se pela elevação do hormônio da paratiroide (PTH), na ausência da elevação dos níveis séricos de cálcio e exclusão de causas secundárias. $\mathrm{O}$ caso descrito ilustra o seguimento de uma mulher na pós-menopausa com NPHPT que evoluiu com múltiplos adenomas. Este caso relata uma paciente de 77 anos de idade que tem dor generalizada crônica e osteoporose. O PTH inicial foi elevado com níveis séricos de cálcio, albumina, fósforo e $250 \mathrm{H}$ vitamina $\mathrm{D}$ normais. A densitometria óssea (DMO) evidenciou um T-SCORE da coluna lombar: -3.0, colo do fêmur: -2.6 e rádio distal: -4.2. Outras causas de hiperparatireoidismo secundário foram descartadas e a ultrassonografia cervical e varredura com Sestamibi foram negativos. Fez uso de alendronato e três infusões de ácido zoledrônico para o tratamento da osteoporose. No décimo ano de seguimento, depois de sucessivas imagens negativas, a ultrassonografia evidenciou um nódulo sugestivo de adenoma de paratireoide inferior direita. A paciente foi submetida à paratireoidectomia, e um exame histológico confirmou a hipótese. A elevação dos níveis séricos de PTH no pós-operatório se manteve com níveis normais de cálcio. A nova ultrassonografia cervical evidenciou outro nódulo sugestivo de adenoma de paratireoide superior direita. Uma segunda paratireoidectomia foi realizada, cujo histológico confirmou outro adenoma de paratireoide. Conclui-se que essa é uma apresentação incomum de NPHPT e destaca as complicações a longo prazo. Arq Bras Endocrinol Metab. 2014;58(5):583-6
1 Division of Endocrinology, Diabetes and Bone Diseases, Agamenon Magalhaes Hospital, Brazilian Ministry of Health, University of Pernambuco (UPE) Medical School, Recife, PE, Brazil

Correspondence to: Francisco Bandeira Disciplina de Endocrinologia, Faculdade de Ciências Médicas, Universidade de Pernambuco Av. Rui Barbosa, 1435 52050-450 - Recife, PE, Brazil fbandeira@gmail.com

Received on Mar/19/2014 Accepted on May/26/2014 DOI: $10.1590 / 0004-2730000003367$ 


\section{INTRODUCTION}

$\mathrm{N}$ ormocalcemic primary hyperparathyroidism (NPHPT) is a condition characterized by elevation of the parathyroid hormone (PTH) in the presence of normal serum calcium and the absence of secondary causes, such as renal insufficiency, vitamin D deficiency, use of medications such as hydrochlorothiazide and lithium, as well as hypercalciuria and malabsorption states. NPHPT was only recognized as a distinct condition at the Third Workshop on Management of Asymptomatic Primary Hyperparathyroidism held in 2008. Its natural history and management are not yet fully established, with few studies and case reports in the literature $(1,2)$. Such cases usually originate in referral centers for bone diseases (3). The epidemiology of this disease is not well defined, due to the different exclusion criteria of secondary causes. In MrOS (The Osteoporotic Fractures in Men Study), the prevalence of normocalcemic hyperparathyroidism was $0.4 \%$ in a population of 2,364 males, while in the DHS (Dallas Heart Study), in a population of 3,450 individuals of males and females, it was 3.1\% (4). As in most cases of primary hyperparathyroidism, the elevation of PTH is the result of a single parathyroid adenoma, which is removed by surgery, leading to clinical and laboratory resolution $(3,5)$. The case described below illustrates the long-term follow-up of a postmenopausal woman with NPHPT patient who progressed with multiple adenomas.

\section{CASE REPORT}

A 77-year-old female was referred to the endocrine clinic for evaluation of chronic generalized pain and osteoporosis. She presented a history of surgical menopause at the age of 45 . Initial serum PTH was $105 \mathrm{pg} /$ $\mathrm{mL}$, with total serum calcium of $9.6 \mathrm{mg} / \mathrm{dL}$, albumin $4.79 \mathrm{~g} / \mathrm{dL}$, phosphorus $2.8 \mathrm{mg} / \mathrm{dL}$, and $25 \mathrm{OHD}$ of
$10.2 \mathrm{ng} / \mathrm{mL}$ (Table 1). Vitamin D supplementation was started and by the end of the first year of followup serum $25 \mathrm{OHD}$ concentrations were $34.6 \mathrm{ng} / \mathrm{mL}$, which remained adequate during the course of treatment. Bone densitometry (BMD) results were as follows: lumbar spine 0.862 (T-score -3.0), femoral neck 0.721 (T-score -2.6) and distal radius -4.2 (Table 2). Serum PTH remained elevated despite adequate serum 25OHD levels. Other causes of secondary hyperparathyroidism were ruled out and cervical ultrasound and Tc-99-Sestamibi scan were negative. Oral alendronate was started.

A follow-up BMD two years later showed no change at the lumbar spine and a 7\% gain at the femoral neck. The patient continued to exhibit elevated serum PTH levels in the presence of normal serum calcium and 25OHD concentrations (Table 1). Cervical imaging continued to be negative for parathyroid enlargement.

Owing to gastrointestinal complaints oral alendronate was replaced by zoledronic acid and the patient continued to exhibit improvements in BMD: 6.9\% gain at the lumbar spine and no change at the femoral neck (Table 2). After the second infusion, further improvements were observed: $3.9 \%$ gain in lumbar spine and $3.3 \%$ in femoral neck and no gain in femoral neck, BMD 0.765, T-score (-1.8) (Table 2). After the third infusion of zoledronic acid, the laboratory values were as follows: serum ionized calcium $1.25 \mathrm{mmol} / \mathrm{L}, \mathrm{PTH}$ $91.5 \mathrm{pg} / \mathrm{mL}, 25 \mathrm{OHD} 43 \mathrm{ng} / \mathrm{mL}$ and C-terminal telopeptide (CTX) $138 \mathrm{pg} / \mathrm{mL}$ (Table 1 ).

In the $10^{\text {th }}$ year of follow-up, after successive negative cervical imaging, ultrasound showed a $0.6 \mathrm{~cm}$-solid nodule suggestive of an enlarged right inferior parathyroid gland. PTH levels in fluid which was obtained during fine-needle aspiration (FNA) were over $5,000 \mathrm{pg} / \mathrm{mL}$ and a Sestamibi scan was negative. The patient underwent parathyroidectomy, and a histological examina-

Table 1. Laboratory data during follow up

\begin{tabular}{|c|c|c|c|c|c|c|c|c|c|}
\hline & 2001-2002 & 2003 & 2005 & 2006 & 2007 & 2008 & 2009 & 2011 & 2012 \\
\hline PTH (pg/mL) & $78-105$ & $56-76$ & $88,2-99,5$ & $65-82$ & $76-101$ & 91,5 & $94-150$ & $51-201$ & 101 \\
\hline Serum calcium (mg/dL) & $9.4-9.6$ & 10 & $9.4-9,6$ & & 9.5 & 9.3 & 9.0 & 9.9 & 9.4 \\
\hline Albumin (g/dL) & 4.79 & 4.5 & 4.2 & & 4.5 & 4.0 & 4.2 & 4.3 & 4.5 \\
\hline Serum ionized calcium (mmol/L) & 1.2 & & 1.1 & 1.15 & & 1.25 & & & \\
\hline Phosphorus (mg/dL) & 2.8 & & 2.7 & & & 2.9 & 2.7 & & \\
\hline Serum 250HD (ng/mL) & 10.2 & 34.6 & & 38 & & 43 & & 36 & 48 \\
\hline Serum CTX (pg/mL) & & & & & & 138 & 219 & 303 & \\
\hline
\end{tabular}

PTH: parathyroid hormone; 250HD: 25-hydroxi-vitamin D; CTX: C-telopeptide. References: PTH: 15-65 pg/mL, serum calcium: 8,5-10,2 mg/dL, albumin: 3,5-5,5 g/dL, serum ionized calcium: 1,05-1,30 mmol/L, phosphorus: 2,5-4,5 mg/dL, serum 250HD: > $30 \mathrm{ng} / \mathrm{mL}$, serum CTX: 60-480 pg/mL. 
Table 2. Bone mineral density (T-score) during follow up previously to parathyroidectomy

\begin{tabular}{lc}
\hline Baseline & T-score \\
\hline LS & -3.0 \\
FN & -2.6 \\
DR & -4.2 \\
Year 2 & \\
LS & -2.75 \\
FN & -1.79 \\
Year 5 & \\
LS & -2.2 \\
FN & -1.8 \\
Year 10 & \\
LS & \\
FN & -2.5 \\
DR & -2.4 \\
\hline
\end{tabular}

LS: lumbar spine; FN: femoral neck; DR: distal radius.

tion confirmed a right inferior parathyroid adenoma of $0.7 \times 0.6 \mathrm{~cm}$, the nodule wasn't intrathyroid and the predominant cell type was oxyphil. Post-operatively serum PTH remained elevated in the presence of normal serum calcium levels. At that time abdominal ultrasound showed no evidence of kidney stones.

During the first year following parathyroidectomy, BMD unexpectedly worsened at the lumbar spine (-7\%) and at the distal radius $(-8 \%)$, excluding other factors that could interfere in BMD (Table 2). At this time, serum PTH was $201 \mathrm{pg} / \mathrm{mL}$, and a follow-up cervical ultrasound showed a $0.6 \mathrm{~cm}$ new solid nodule suggestive of an enlarged right superior parathyroid gland, again with a negative Tc-99-Sestamibi scan. PTH levels in the aspiration fluid were remarkably high $(19,600 \mathrm{pg} / \mathrm{mL})$ suggesting a new parathyroid adenoma as a cause of the elevated PTH levels. A second parathyroidectomy was performed, with the excision of a histologically confirmed parathyroid adenoma.

\section{DISCUSSION}

Elevation of serum PTH may be a finding during evaluation of reduced bone mass and, when associated with the absence of hypercalcemia, causes of secondary hyperparathyroidism should be excluded in order to confirm the diagnosis of normocalcemic primary hyperparathyroidism. There is uncertainty regarding NPHPT as an incipient presentation of classic primary hyperparathyroidism, but in the present case over 10 years of follow-up the disease progressed without the development of hypercalcemia, suggesting that it may be an independent condition.

There are few data available regarding complications and the natural history of NPHPT. Lowe and cols. reported a follow-up of 37 patients, of whom 29 were postmenopausal women, 6 premenopausal women and 2 males, with a mean age of 58 years with normal renal function. They considered serum 25OHD above 20 $\mathrm{ng} / \mathrm{mL}$ as an inclusion criterion $(65 \%$ had levels above $30 \mathrm{ng} / \mathrm{mL}$ ). In the follow up analysis, there were 4 fragility fractures, $14 \%$ had nephrolithiasis and $57 \%$ had osteoporosis at diagnosis. Parathyroidectomy was performed in 10 subjects, in whom the presence of two parathyroid adenomas and hyperplasia was observed in 2 cases, while the others showed a single parathyroid adenoma (6).

In our institution, a study on 33 patients compared data on NPHPT with asymptomatic hypercalcemic PHPT (5). The following inclusion criteria for the diagnosis of NPHPT were used: serum 25OHD levels above $30 \mathrm{ng} / \mathrm{mL}$, no use of bisphosphonates, thiazide diuretics, anticonvulsants or lithium, estimated glomerular filtration rate above $60 \mathrm{~mL} / \mathrm{min}$ (MDRD-Modification of Diet in Renal Disease), and absence of hypercalciuria and malabsorption diseases. Mean age was 64 years, and $79 \%$ were female. There was a high prevalence of nephrolithiasis (18\%), suggesting that normocalcaemia does not preclude clinical manifestations. It was also observed that bone mineral density at the distal radius was better preserved in the group with normal calcium serum than in the group with hypercalcemia. In our case, the patient presented predominantly with osteoporosis, which initially showed some response to bisphosphonates but subsequently progressed to a more rapid bone loss without the development of hypercalcemia. There was no evidence of nephrolithiasis during follow-up.

Other studies have evaluated the presence of osteoporosis and nephrolithiasis in NPHPT. Tordjman and cols., evaluated a cohort comprising 32 patients with normocalcemic hyperparathyroidism and found a high prevalence of osteoporosis (36\%), with $9 \%$ presenting nephrolithiasis (7). Cakir and cols., in their investigation of 18 patients with normocalcemic hyperparathyroidism and a mean age of 50 years ( $47 \%$ female) found that $47 \%$ had osteoporosis and $11 \%$ nephrolithiasis (8).

Wade and cols. presented a cohort of 93 patients with primary hyperparathyroidism, of whom 58 pa- 
tients $(62 \%$ of the sample) had serum ionized calcium measured preoperatively. Eighty percent had elevated levels and $14 \%$ normal levels. The mean age was 60 years, $63 \%$ were female, $13 \%$ had a history of bone fragility fracture and $25 \%$ had nephrolithiasis. Of the patients with normal serum ionized calcium, 5 (62\%) subjects had a single adenoma at surgery and $3(28 \%)$ had multiple adenomas (9). Our patient always had normal serum ionized calcium concentrations.

Cervical ultrasonography was effective in localizing the parathyroid lesions in the present case although it took almost a decade of follow-up and repeated normal ultrasound examinations for those lesions become apparent. The Tc-99-Sestamibi scan was less sensitive, failing to localize either adenoma. The sensitivity of ultrasound is highly operator-dependent, but its accuracy may be as high as $88 \%$ in asymptomatic hypercalcemic patients (10). When it detects intra-thyroid nodules, FNA with measurement of PTH in the aspiration fluid is very useful as thyroid nodules may cause false-positive Sestamibi scan results (11). In the present case both adenomas had very high PTH levels in their aspiration fluid. Multiphase computed tomography of the cervical region (4D-CT) has became the preferred localizing method for those patients in whom the parathyroid lesion is not detected by ultrasound or scintigraphy, as its sensitivity is high for both adenoma and hyperplasia (12). Until the issue of long-term complications of NPHPT is not completely understood, it seems reasonable to consider surgery for those patients in whom the parathyroid lesion is localized by imaging procedures or traditional operation (neck exploration) for those who have osteoporosis or renal stone disease with negative imaging.

In conclusion, this case illustrates an unusual presentation of NPHPT and highlights the long-term complications, irrespective of the development of hypercalcemia.

Disclosure: no potential conflict of interest relevant to this article was reported.

\section{REFERENCES}

1. Bilezikian JP, Khan AA, Potts JT. Guidelines for the management of asymptomatic primary hyperparathyroidism: summary statement from the Third International Workshop. J Clin Endocrinol Metab. 2009;94(2):335-9.

2. Bilezikian JP, Silverberg SJ. Normocalcemic primary hyperparathyroidism. Arq Bras Endocrinol Metabol. 2010;54(2):106-9.

3. Cusano NE, Silverberg SJ, Bilezikian JP. Normocalcemic primary hyperparathyroidism. J Clin Densit. 2013;16(1):33-9.

4. Cusano NE, Naim MM, Wang PY, Zhang C, Cremers SC, Haney $E M$, et al. Normocalcemic hyperparathyroidism and hypoparathyroidism in two community-based nonreferral populations. J Clin Endocrinol Metab. 2013;98(7):2734-41.

5. Amaral LM, Queiroz DC, Marques TF, Mendes M, Bandeira F. Normocalcemic versus hypercalcemic primary hyperparathyroidism: more stone than bone? J Osteoporos. 2012;3:128-352.

6. Lowe H, McMahon DJ, Rubin MR. Normocalcemic primary hyperparathyroidism: further characterization of a new clinical phenotype. J Clin Endocrinol Metab. 2007;92(8):3001-5.

7. Tordjman KM, GreenmanY, Osher E. Characterization of normocalcemic primary hyperparathyroidism. Am J Med. 2004;117:861-3.

8. Cakir I, Unluhizarci K, Tanriverdi F. Investigation of insulin resistance in patients with normocalcemic primary hyperparathyroidism. Endoc. 2012;42:419-22.

9. Wade TJ, Yen TWF, Amin AL, Wang TS. Surgical management of normocalcemic primary hyperparathyroidism. World J Surg. 2012;36:761-6.

10. Bandeira F, Griz L, Chaves N, Carvalho NC, Borges LM, Castro ML, et al. Diagnosis and management of primary hyperparathyroidism - A scientific statement from the Department of Bone Metabolism, the Brazilian Society for Endocrinology and Metabolism. Arq Bras Endocrinol Metab. 2013;57(6):406-24.

11. Khang AR, Kim EK, Namm EY, Byeon SJ, Kim JH, Ohn JH, et al. Primary hyperaparathyroidism due to cystic parathyroid adenoma not detected on ${ }^{99 m}$ Tc-Sestamibi scan. Endocrinol Metab. 2012;27:83-8.

12. Chazen JL, Gupta A, Dunning A, Phillips CD. Diagnostic accuracy of 4D-CT for parathyroid adenomas and hyperplasia. Am J Neuroradiol. 2012;33(3):429-33. 